\title{
Effect of Growth Hormone on Total Cholesterol and Body Composition in Children with Non-Endocrine Short Stature, Partial Growth Hormone Deficiency and Growth Hormone Neurosecretory Dysfunction
}

\author{
Hirohiko Higashino, Naoyuki Kitamura, Yohnosuke Kobayashi, Hakuo Takahashi and Norihiro Nishino \\ Departments of Pediatrics (HH, NK, YK), Clinico-Laboratory Medicine (HT,NN), Kansai Medical University, \\ Osaka, Japan
}

\begin{abstract}
Total cholesterol (TC) level and percent ideal body mass index (\%BMI) for age and height were measured in children with non-endocrine short stature (NESS)(n=11), partial growth hormone deficiency $(\mathrm{PGHD})(\mathrm{n}=4)$ and growth hormone neurosecretory dysfunction (GHND)(n=5) every 3 months for 2 years to evaluate the effect of growth hormone $(\mathrm{GH})$ therapy. These measurements and annual growth rates were compared among three groups: group A (children who remained prepubertal during the study); group B (children who started puberty in the second year); group C (children who started puberty in the first year). There was no significant change in \%BMI during the study period in the three groups and no significant correlation between \%BMI and height velocity or height standard deviation (SD) before treatment or height gain after treatment. TC levels remained unchanged in groups $\mathrm{A}$ and $\mathrm{B}$. However, there were significant decreases in group $\mathrm{C}$ after treatment. These results showed that the GH therapy in NESS, PGHD and GHND children had no effect on cholesterol metabolism or body composition, and that the children's nutritional status did not affect their natural growth.
\end{abstract}

Key words: short stature, growth hormone, body mass index, total cholesterol

\section{Introduction}

GH has a potent effect on carbohydrate, lipid, and protein metabolism. Children with GH deficiency have an increased fat mass, which is reduced by GH treatment (1). In adults, GH deficiency is also associated with an

\footnotetext{
Correspondence: Dr. Hirohiko Higashino, Department of Pediatrics, Kansai Medical University, 10-15, Fumizono-cho, Moriguchi-shi, Osaka 570 Japan
}

increase in fat and a decrease in muscle mass (2), and they are at increased risk for developing cardiovascular disorders. This may be because $\mathrm{GH}$ has a role in the control of lipoprotein metabolism (3). GH treatment increases lean body mass and decreases fat mass (4). These results lend support to the necessity of life-long use of $\mathrm{GH}$ therapy in patients with complete growth hormone deficiency. However, most children who are treated with $\mathrm{GH}$ because of short stature in Japan do not have 


\section{Higashino et al.}

complete GH deficiency, but they are patients with NESS, PGHD and GHND.

Children with NESS are leaner than the normal population (5). It is known that obese children have reduced spontaneous GH secretion (6), but even within the normal range, body mass index is inversely related to $\mathrm{GH}$ secretion in normal and short stature children (7).

The present study was undertaken to attempt to evaluate the effect of GH therapy on body composition and serum cholesterol in children with NESS, PGHD and GHND. The role of body mass and the effect of age on the response to growth hormone therapy were also studied.

\section{Subjects and Methods}

\section{Patients}

Twenty children with short stature who were below -2 SD from the mean height for age ( 15 males and 5 females) were enrolled in the study. They were classified into three categories (NESS 11, M/F=8/3, $10.0 \pm 2.4$ year. PGHD 4, M/F=4/0, $12.9 \pm 1.7$ year. GHNSD 5, $\mathrm{M} / \mathrm{F}=3 / 2,11.0 \pm 0.8$ year.) based on the results of provocation tests of growth hormone secretion and the excretion of urinary growth hormone (8). Recombinant human growth hormone $(\mathrm{hGH})$ was administered subcutaneously at a dose of $0.5 \mathrm{U} / \mathrm{kg}$, divided into 4 to 6 doses per week. They were followed-up every 3 months for two years and divided into three groups in regard to their pubertal status during the study. The onset of puberty was defined as a testicular volume of $4 \mathrm{~mL}$ or more in boys and breast development to Tanner stage 2 in girls.
Group A: children who remained prepubertal during the study. ( $\mathrm{n}=7$, mean age $9.5 \pm 2.2$ year, $\mathrm{M}: \mathrm{F}=6: 1$, NESS 5, PGHD 1, GHNSD 1)

Group B: children who entered puberty in the second year $(n=6$, mean age $10.4 \pm 1.7$ year, $\mathrm{M}: \mathrm{F}=5: 1$, NESS 4, PGHD 1, GHNSD 1).

Group C: children who entered puberty in the first year ( $n=7$, mean age $12.6 \pm 1.4$ year, $\mathrm{M}: \mathrm{F}$ 4:3, NESS 2, PGHD 2, GHNSD3)(Table 1).

\section{Methods}

Auxological measurements and serum total cholesterol levels were recorded at every visit. Body mass index (BMI), the ratio of weight $(\mathrm{kg})$ and height ${ }^{2}\left(\mathrm{~m}^{2}\right)$, and \%BMI (BMI expressed as a percentage of the BMI of a child of the same age whose weight and height were on the 50 th centiles, and of the same height whose weight was on the 50 th centiles) were determined for each child. They were expressed as \%BMI for age and \%BMI for height, respectively. Changes of the above measurements were compared and the relationship between $\% \mathrm{BMI}$ and height SD, growth velocity, delta $(\Delta)$ height SDS, and serum total cholesterol levels were analyzed. The net height gain was compared in group A between the children who started GH treatment under 10 years of age and above 10 years of age.

\section{Statistics}

Results were expressed as the mean $\pm \mathrm{SD}$. The unpaired student $t$ test was used for the difference of net height gain in group A. The relationships between \%BMI and height SD, growth velocity, $\Delta$ height SDS, and serum total cholesterol level were analyzed by linear regression. Comparisons of group mean para- 


\section{GH Effect on TC and BMI in NESS, PGHD and GHND}

meters and tests for significant differences among the means of total cholesterol, \%BMI for age and height were made at every attendance using analysis of variance and Bonferroni adjustment to the $p$ values. The level of statistical significance was taken as $p<0.05$.

\section{Results}

\section{Subjects characteristics (Table 1)}

Table 1 shows the characteristics of each group. The chronological age of group $\mathrm{C}$ was significantly older than group A. \%BMI for age was under $100 \%$ in all groups, but \%BMI for height varied among three groups. \%BMI for age in group $\mathrm{C}$ was smaller than in the other groups and \%BMI for height and obesity index was also significantly smaller in group $\mathrm{C}$ than group B. There were no significant differences in height SD, serum total cholesterol levels or growth rates before GH therapy among three groups.

There was no correlation between \%BMI for age or height and height SD, growth rate, $\Delta$ height SDS and total cholesterol level in all groups.

Table 1 Subjects Characteristics.

\begin{tabular}{|c|c|c|c|c|c|c|c|c|}
\hline$\underset{(n)}{\text { Group }}$ & $\mathrm{M} / \mathrm{F}$ & $\begin{array}{c}\mathrm{CA} \\
(\mathrm{SD})\end{array}$ & $\begin{array}{l}\text { Height } \\
\text { SD } \\
\text { (SD) }\end{array}$ & $\begin{array}{c}\text { \%BMl for } \\
\text { age } \\
\text { (SD) }\end{array}$ & $\begin{array}{c}\text { \%BMl for } \\
\text { height } \\
\text { (SD) }\end{array}$ & $\begin{array}{c}\text { Obesity } \\
\text { Index } \\
\text { (SD) }\end{array}$ & $\begin{array}{c}\mathrm{TC} \\
(\mathrm{mg} / \mathrm{dl}) \\
(\mathrm{SD})\end{array}$ & $\begin{array}{c}\text { Growth rate } \\
(\mathrm{cm} / \mathrm{yr}) \\
(\mathrm{SD})\end{array}$ \\
\hline $\begin{array}{c}A \\
(7)\end{array}$ & $6 / 1$ & {$\left[\begin{array}{c}9.5 \\
(2.2)\end{array}\right.$} & $\begin{array}{l}-3.20 \\
(1.08)\end{array}$ & {$\left[\begin{array}{c}92.20 \\
(12.21)\end{array}\right.$} & $\begin{array}{l}98.49 \\
(9.76)\end{array}$ & $\begin{array}{l}-1.60 \\
(9.89)\end{array}$ & $\begin{array}{l}170.0 \\
(24.9)\end{array}$ & $4.1(0.9)$ \\
\hline $\begin{array}{c}B \\
(6)\end{array}$ & $5 / 1$ & $\begin{array}{l}10.4 \\
(1.7)\end{array}$ & $\begin{array}{l}-2.93 \\
(0.5)\end{array}$ & $\left.\begin{array}{l}94.96 \\
(4.72)\end{array}\right]$ & $\begin{array}{l}105.31 \\
(6.75)\end{array}$ & $\left.\begin{array}{c}4.20 \\
(5.94)\end{array}\right]$ & $\begin{array}{r}175.7 \\
(15.9)\end{array}$ & $4.3(0.6)$ \\
\hline $\begin{array}{c}C \\
(7)\end{array}$ & $4 / 3$ & $\begin{array}{r}L_{12.6} \\
(1.4)\end{array}$ & $\begin{array}{l}-2.57 \\
(0.68)\end{array}$ & $\begin{array}{c}{\left[\begin{array}{l}82.50 \\
(6.03)\end{array}\right]} \\
\end{array}$ & $\begin{array}{l}90.75 \\
(5.68)\end{array}$ & $\begin{array}{l}-9.09 \\
(5.69)\end{array}$ & $\begin{array}{l}185.5 \\
(20.3)\end{array}$ & $4.1(1.2)$ \\
\hline
\end{tabular}

$\because$ P $<0.05$. CA: Chronological Age(yrs), TC: Total cholesterol(mg/dl)

\section{Changes of serum total cholesterol levels} (Fig. 1)

There was no significant change in total cholesterol level during the study in groups $\mathrm{A}$ or B. In group $\mathrm{C}$, serum total cholesterol decreased significantly after GH therapy. $\% \mathrm{BMI}$ for age and height remained unchanged throughout the study in all groups. Changes of \%BMI varied in each individual. When expressed as \%BMI for age, 3 out of 20 children were above $100 \%$ and as $\%$ BMI for height, 9 out of 20 were above $100 \%$.

\section{Height gain after GH treatment (Table 2,} Fig. 2)

In group $\mathrm{A}$, the growth rate of children under 10 years of age decreased in the second year, and net height gain(height velocity after GH treatment minus height velocity before therapy; $\mathrm{cm} /$ year) when compared with the children who started GH therapy above or under 10 years, did not change in the first year ( $3.0 \pm 1.8$ vs. $2.3 \pm 0.3$, not significant (NS)), but there was much difference in the second year $(2.7 \pm 1.2$ vs. $0.2 \pm 1.3, \mathrm{p}<0.05)$. There was no significant difference between the two groups in terms of total cholesterol and \%BMI for age and height.

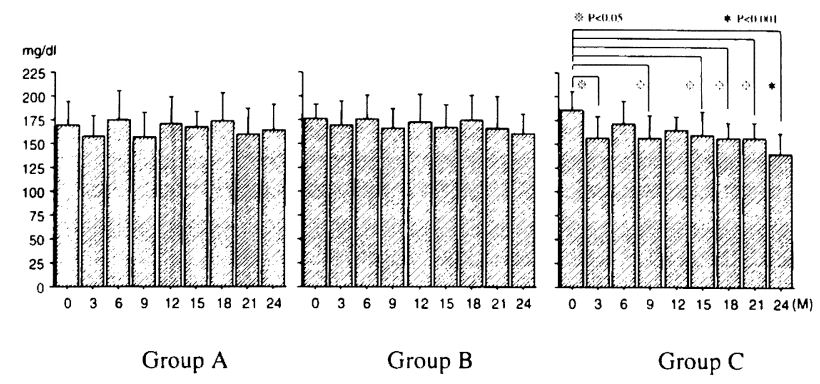

Fig. 1 Changes in serum total cholesterol level in each group after growth hormone therapy. 


\section{Higashino et al.}

Table 2 Net height gain after GH theraphy compared with pretreatment growth rates.

\begin{tabular}{lccc}
\hline $\begin{array}{l}\text { Year of } \\
\text { Therapy }\end{array}$ & \multicolumn{2}{c}{ Net Height Gain(cm/yr) } & \\
\cline { 2 - 3 }$(\mathrm{n}=3)$ & $\begin{array}{c}<10 \mathrm{yr} \\
(\mathrm{n}=4)\end{array}$ & \\
\hline First & $2.3 \pm 1.8$ & $2.3 \pm 0.3$ & NS \\
Second & $2.7 \pm 1.2$ & $0.2 \pm 1.3$ & $<0.05$ \\
\hline
\end{tabular}

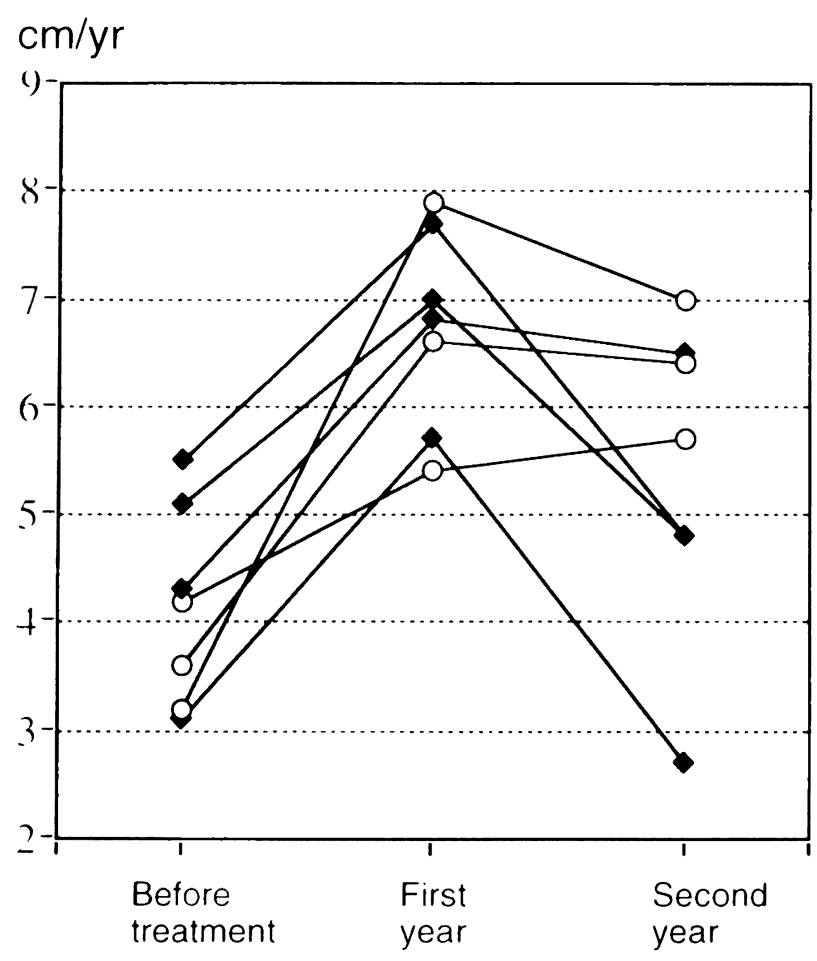

Fig. 2 Growth rate before and after GH therapy. $(C ;>10$ year, $\diamond ;<10$ year)

\section{Discussion}

Our study showed that children with NESS and PGHD were leaner than normal and that their age was important in regard to the response of GH therapy. There was no correlation between \%BMI and height SD, growth velocity, total cholesterol level, delta height
SDS and \%BMI for age. The height and total cholesterol levels did not change after GH treatment in our study.

Other investigators have reported that children with idiopathic short stature are leaner than normal and have showed that BMI is positively correlated with height, height velocity and plasma insulin-like growth factor I (IGF-I)(9). Adequate nutrition is considered to be necessary for the action of $\mathrm{GH}$ on plasma IGF-I and the growth-promoting action of IGFI. This may influence the basal situation and the response to hGH therapy. Variations in the growth response of the hGH-treated idiopathic short stature children may partly be explained by variations in their nutritional intake. Martha (10) reported that pretreatment BMISDS (expressed as standard deviation score for age) did not correlate with either growth velocity or serum IGF-I, but after 12 months of GH therapy, BMI-SDS correlated positively with changes in plasma IGF-I and growth velocity; BMI-SDS did not change during treatment. It is thought that the association with increased growth hormone binding protein, a higher absolute GH dose, and a high GH dose relative to endogenous production contributed to the correlation between BMI and growth response. Since BMI does not reflect body fat mass, a bioelectrical impedance method and magnetic resonance imaging were used to evaluate the effect of GH on the change in adiposity in the children with growth hormone deficiency (11, 12)

There was no correlation between \%BMI for age and height and height SD, growth velocity, total cholesterol level, and delta height SDS after GH in this study. When expressed as $\%$ BMI for age, 3 out of 20 children were above 


\section{GH Effect on TC and BMI in NESS, PGHD and GHND}

$100 \%$ and as \%BMI for height, 9 out of 20 were above $100 \%$. There was heterogeneity in our study for age, gender, and body composition of the patients. A longer study would be needed to elucidate the mechanism of the variations in growth response to $\mathrm{GH}$.

Hypercholesterolemia in children with constitutional growth delay has been reported and there is a negative correlation between the serum total cholesterol and annual height gain (13). In adult GH deficient patients, there is a significant decrease in plasma cholesterol after 6 months of GH therapy (14) but Whitehead et al. found no change (15). Edén reported increased high density lipoprotein (HDL)-cholesterol and decreased low density lipoprotein (LDL)-cholesterol levels after GH therapy in adults with GH deficiency (16). There was no change in total cholesterol during the study in groups A and B. GH treatment had no apparent effect on increase in lipolysis sufficient to reduce the total cholesterol to that of children with NESS and PGHD. It is considered that these children with NESS, PGHD and GHND may have sufficient $\mathrm{GH}$ secretion to regulate cholesterol metabolism. In group $\mathrm{C}$, The total cholesterol levels decreased after GH therapy, and since they entered puberty during the first year, this phenomenon was probably an effect of sex steroids.

The response to GH therapy in the children who started the GH before 10 years of age was lower than in children above 10 years of age in group A. This difference seemed to be due to differences in the basal level of sex steroids before the onset of puberty. Since it is known that the response of $\mathrm{GH}$ treatment lessens each year (17), it is suggested that the dose of hGH should be increased every year in younger children until pubertal development starts.

To achieve the optimal response to $\mathrm{GH}$ therapy, it is important to consider the relationships between age, body mass and nutritional state in children with NESS and PGHD.

\section{References}

1. Collipp PJ, Curti V, Thomas J, Sharma RK, Maddaiah VT, Cohn SH. Body composition changes in children receiving human growth hormone. Metabolism 1973; 4: 58995.

2. Deboer H, Blok GJ, Voerman HJ, Vries JM, Van Der Veen EA. Body composition in adult growth hormone deficient men, assessed by anthropometry and bioimpedance analysis. J Clin Endocrinol Metab 1992; 75: 833-7.

3. Rosén T, Bengtsson B-Å. Premature cardiovascular mortality in hypoptuitarism-a study of 333 consecutive patients. Lancet 1990; 336: 285-8.

4. Cuneo RC, Salmon F, Wiles CM, Hesp Rand Sönksen PH. Growth hormone treatment in growth hormone deficient adults. effect on muscle mass and strength. J Appl Physiol 1991; 70: 449-53

5. Thibault H, Souberbielle JC, Taieb C, Brauner R. Idiopathic prepubertal short stature is associated with low body mass index. Horm Res1993; 40: 136-40

6. Bercu BB, Shulman DI, Root AV. Obesity decreases endogenous growth hormone secretion in children with normal growth velocities. Pediatr Res 1988; 23: 272A (Abst.)

7. Patel L, Skinner D, Price DA, Clayton PE. 


\section{Higashino et al.}

The influence of body mass index on growth hormone secretion in normal and short stature children. Growth Regul 1994; 4: 2934

8. Higashino $\mathrm{H}$, Kitamura N, Ikemoto $\mathrm{Y}$, Kobayashi Y. Effect of human growth hormone (GH) therapy on non-endocrine short stature (NESS) compared with GH deficient children and factors which predict the response to GH therapy. Clin Pediatr Endocrinol Suppl 4 1994; 129-32

9. Thibault H, Souberbielle JC, Taieb C, Brauner R, Idiopathic prepubertal short stature is associated with low body mass index. Horm Res 1993; 40: 136-40

10. Martha PM, Reiter EO Jr, Dávila N, Shaw MA, Holcombe JH, Baumann G. The role of body mass in the response to growth hormone therapy. J Clin Endocrinol Metab 1992; 75: 1470-3

11. Gregory JW, Green SA, Jung RT, Scrimgeour CM, Rennie MJ. Metabolic effects of growth hormone treatment: an early predictor of growth response? Arch Dis Child 1993; 68: 205-9

12. Leger J, Carel C, Legrand I, Paulsen A, Hassan M, Czernichow P. Magnetic resonance imaging evaluation of adipose tissue and Muscle tissue mass in children with growth hormone (GH) deficiency, Turner's syndrome, and intrauterine growth retar- dation during the first year of treatment with GH. J Clin Endocrinol Metab 1994; 78: 904-9

13. Miyamoto N, Tsuji M, Shirakawa N, Kuroda Y. Hypercholesterolemia in children with constitutional dwarfism. J Jpn Pediatr Soc 1989; 93: 2462-6. (Jpn)

14. Salmon F, Cuneo RC, Hesp R, Sönksen PH. The effects of treatment with recombinant human growth hormone on body composition and metabolism in adult with growth hormone deficiency. N EngI J Med 1989; 321: 1797-803.

15. Whitehead HM, Boreham C., Mcllrath EM, Sheridan B, Kennedy L, Atkinson AB. et al. Growth hormone treatment of adult with growth hormone deficiency: results of a 13month placebo controlled cross-over study. Clin Endocrinol (Oxf) 1992; 36: 45-52

16. Edén S, Wiklund O, Oscarsson J, Rosén T, Bengtsson B-Å. Growth hormone treatment of growth hormone-deficient adults results in a marked increase in $\mathrm{Lp}(\mathrm{a})$ and HDL cholesterol concentrations. Arterioscler Thromb Vasc Biol 1993; 13: 296-301

17. Tanaka T, Hibi I, Takano K, Suwa S, Shizume $\mathrm{K}$ and the Non-Endocrine Short Stature Study Group. Three year results of growth hormone (GH) treatment in children with non-endocrine short stature. Clin Pediatr Endocrinol Suppl 4 1994; 27-36. 